RPA Journals

\section{ITHJ}

International Tourism and Hospitality Journal

Journal Homepage: https://rpajournals.com/ithj

\title{
The Relationship between Service Quality Dimensions and Behavioral Intentions in the Egyptian Hotel Industry
}

\author{
Ahmed E. Baiomy \\ Faculty of Tourism and Hotel Management \\ Helwan University, Cairo, Egypt.
}

\begin{abstract}
This study investigates the service quality dimensions within five-star hotels and how these dimensions further impact customer satisfaction and behavior intentions. A selfadministrated questionnaire was used to collect the primary data of this study. The findings obtained from the factor analysis indicated five dimensions of service quality: tangibles, adequacy in service quality, understanding and caring, assurance, and convenience. The findings also indicated that the business guests had the highest importance for the dimensions of assurance, adequacy in service supply, understanding and caring, tangibles, and convenience. Although the findings of this study indicated that the adequacy in service supply, assurance, understanding, and caring in the hotels were rationally good, lower ratings were identified for other numerous factors. Multiple regression analysis was also applied and showed that these five dimensions had a statistically significant influence on customer satisfaction and behavior inventions.
\end{abstract}

Keywords: Customer Satisfaction, SERVQUAL, Service Quality, Behavioral Intentions,

*Corresponding author: Ahmed E. Baiomy; E-mail: ahmadbaiomie@gmail.com DOI: https://doi.org/10.37227/ITHJ-2020-04-179

\section{Introduction}

The tourism industry is the world's biggest industry contributing to developing countries (Jones \& Haven-Tang, 2005). Egypt is a traditionally tourism-based economy, and the long-standing, strong market fundamentals make the country a good investment opportunity in the long term (Colliers, 2013). The tourism industry in Egypt has been severely influenced since 2011, in which Egypt's inbound tourism dropped by 33\% (Colliers, 2013). Service is one of the most critical factors for hotels in order to gain a competitive advantage in the hospitality industry (Angelova and Zekiri, 2011). Although homogenous types of services have been offered in different hotels, the quality of service is one of the ultimate differentiators (Salazar et al., 2010). Hung et al. (2003) revealed that providing customers with outstanding service quality impacts their satisfaction and 
enhances their profits. Today's customers are frequently traveled and know what they want (Chacko et al., 2012).

In the hospitality industry, customer satisfaction is the secret to success in severe competition by fulfilling customers' wants (Radojevic et al., 2015). Customer satisfaction is an essential factor in providing the best service quality in hotels (Said et al., 2013). According to Pizam et al. (2015), hotels should deliver high-quality service to improve customer satisfaction and differentiate them from competitors. Customers are considered to be satisfied when the weighted sum of their total experiences exceeded their expectations. Thus, hotel managers should be aware of factors that contribute to customer satisfaction.

El Saghier (2015) indicated that improving the service quality levels through using the SERVQUAL model is vital to satisfy customer expectations in Alexandria hotels in Egypt. Hence, this paper attempts to identify the importance and performance of service quality in five-star hotels in Greater Cairo in Egypt. Such a model is designed to measure service components that generate satisfaction within five dimensions provided by the SERVQUAL model. The current study identifies the gaps between customers' expectations and perceptions of the services offered. It is argued that the existence of these gaps is a source of dissatisfaction with the services provided. The present study also extends the service quality model developed by El Saghier (2015), which measured the relationships between the five dimensions of SERVQUAL and customer satisfaction. This study addresses the following main research questions:

- Is there any meaningful difference between customers' expectations and their perceptions of service quality dimensions in the Egyptian Hotel Industry?

- Which quality attributes are perceived to have more/less important to customers, and which ones have high/low-performance levels?

- What is the nature of the relationship between service quality, customer satisfaction, and behavioral intentions?

This paper aims to examine the relationships between the five dimensions of service quality and its subsequent effect on customers' satisfaction and their behavioral intentions in the Egyptian hospitality context. By identifying the nature of the relationship among these dimensions, Hotels' managers will develop better marketing strategies for their target customers.

\section{Literature Review and Hypotheses Development}

In the context of the hospitality industry, the measurement of service quality is critical to understanding customer expectations, the dimensions of the service quality, and their relative importance for customers (Ebrahimpour \& Haghkhah, 2010; Markovic \& Jankovic, 2013). Such measurement will improve the overall service quality levels by recognizing specific service elements requiring improvement (Akbaba, 2006). In addition, when the SERVQUAL instrument was applied over time, it helped service providers understand both customer expectations, perceptions of specific services, and areas of needed quality improvements (Saleh \& Ryan, 1992; Parasuraman et al., 1998; Zeithaml et al., 1990). The conceptual framework of this study was adapted from the studies of Akbaba (2006) and El Saghier (2015), as shown in (Figure 1) 
Figure 1: Theoretical framework

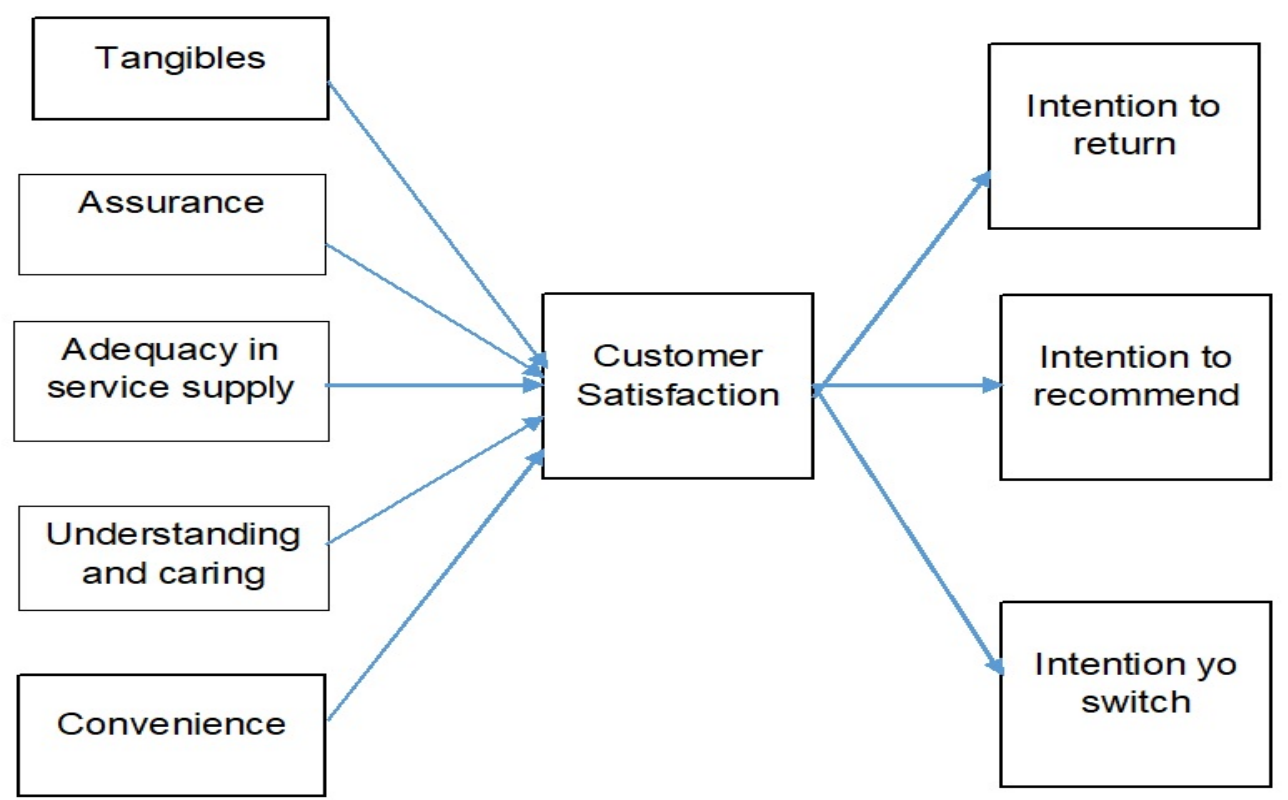

The relationship between reliability and customer satisfaction

Reliability (adequacy in service supply) refers to the ability to deliver the promised service consistently and dependably (Abu Alroub et al., 2012). Consistency means uniformity of the quality, doing things in the same way, and depending on the same standards (Iberahim et al., 2016). Frei et al. (1999) suggested that service quality should include compatibility of the promised service output around a typical target value determined by the customer, while dependability refers to the assurance of providing services as customers expected (Iberahim et al., 2016). Reliability has a significant impact on customers' satisfaction through handling their services' problems, performing them right from the first time and within the promised time, and maintaining error-free records. (Iberahim et al., 2016; Omar et al., 2015; Gagnon \& Roh, 2008). Hossain (2019) indicated that reliability has a positive impact on customer satisfaction. Based on the above review of literature, the following hypothesis was derived:

H1: Perception of adequacy in service supply positively influences customer satisfaction.

The relationship between assurance and customer satisfaction

Assurance perceived by customers is a vital dimension of service quality in any industry (Zeithaml, 2009). It is defined as: "the employees' knowledge and courtesy and the service provider's ability to inspire trust and confidence" (Zeithaml et al., 2006, 119). If trust and confidence are not appropriately conveyed to the customers, their assessment of that provider's service quality will be lower, and their satisfaction may be affected negatively. By communicating competencies through their personnel, service providers can help manage customers' expectations, and in turn, quality concerning this customer service element will be high. It occurs through matching customers' expectations with what service providers promised to deliver; if there are gaps, improvements should be tracked through regular surveys to determine such expectations (Zeithaml, 2009). Munhurrun (2012) \& Hossain (2019) showed that assurance positively impacts customer satisfaction. Based on the above review of literature, the following hypothesis was derived:

$\mathrm{H} 2$ : Perception of assurance positively influences customer satisfaction. 
The relationship between empathy and customer satisfaction

Empathy (understanding and caring) is defined as the "caring, individualized attention the firm provides its customer" (Zeithaml et al., 2006, 120) through which the customer is treated as if he is unique and special. This dimension is more applicable in industries where building relationships with customers ensures the firm's survival as in the hospitality industry, opposing "transaction marketing" (Andaleeb \& Conway, 2006). Empathy may be essential to ensure customer satisfaction and loyalty as the service provider knows how the customer likes his /her services (Harr, 2008). Munhurrun (2012) and Hossain (2019) showed that empathy has a statistically significant impact on customer satisfaction. Based on the above review of literature, the following hypothesis was derived:

H3: Perception of understanding and caring positively influences customer satisfaction

\section{The relationship between responsiveness and customer satisfaction}

Responsiveness (convenience) to the speed of the service providers to respond to the customers' needs. The response requires the presence of willingness and flexibility to help customers and provide prompt service (Zeithaml et al., 2006; Abu Alroub et al., 2012). To be responsive, a firm must determine how long it would take to get answers or have the customers' problems dealt with from the customers' perspective rather than its perspective (Zeithaml et al., 2006). Mariappan (2006) indicated that information technology had brought serious changes in the business environment, especially in the convenience' of service delivery and creation of value-added services that will bring up customers' satisfaction (Zhu et al., 2002). Munhurrun (2012) and Hossain (2019) showed that responsiveness was the strongest predictor of customer satisfaction. Based on the above review of literature, the following hypothesis was derived:

H4: Perception of convenience positively influences customer satisfaction.

\section{The relationship between tangibles and customer satisfaction}

Tangibility refers to the environment in which the service is delivered. It also includes any tangible commodities that facilitate the service's performance or communication (Zeithaml and Bitner, 1996:111). Santos (2002:294) refers to tangibility as the visible facilities of a service such as the appearance of physical aspects, tools and equipment, personnel, and communication material. The importance of tangibility or creating an attractive physical environment has gained growing attention among scholars in the hospitality industry. It is a critical factor for attracting and satisfying more customers (Han and Ryu, 2009). According to several authors (e.g., Ryu and Jang, 2008; MunPanda and Satyabrat, 2014) physical environment has a significant impact on the customer's perception of the service's overall quality turn, which affects customer satisfaction in the hospitality industry. Munhurrun (2012) and Hossain (2019) indicated a positive relationship between tangibles and customer satisfaction. Based on the above review of literature, the following hypothesis was derived:

H5: Perception of tangibles positively influences customer satisfaction.

Moreover, this study's behavioral intentions indicators are the following: the intention to return, intention to recommend to friends and relatives, and intention to switch from the current service provider. (Homburg and Giering 2001, Oppermann, 2000; Bigné et al., 2001; Chen and Gusoy, 2001; Cai et al., 2003; Niininen et al., 2004; Petrick, 2004; Burnham et al., 2003; Carter et al., 2014; Ting, 2014). The relationship between customer satisfaction and each of these indicators will be discussed in turn. 


\section{The relationship between customer satisfaction and intention to return}

Several authors (Fornell, 1992; Bigne et al., 2001; Pike, 2002; Chen and Tsai, 2007; Chi and $\mathrm{Qu}, 2008$; Chen and Chen, 2010) emphasized that perceived quality, customer satisfaction are the most frequent factors used to explain the customer's intention to visit/revisit. Weiss (2003) and Weiss et al. (2004) concluded that high customer satisfaction, along with better service quality, is simultaneously the most significant attribute in predicting repeat purchase behavior (intent to return). Lately, Um et al. (2006) concluded that satisfaction is considered both a predictor of revisiting intention and as a moderator between such intention and perceived attractiveness, perceived quality of service, and perceived value for money. Munhurrun (2012) showed that customer satisfaction has a significant impact on customers' intention to revisit. Based on the above review of literature, the following hypothesis was derived:

H6: Customer satisfaction positively influences customers' intention to return.

H7: Customer Satisfaction mediates the influence of the five dimensions of service quality on the intention to return.

When people sharing their positive or negative evaluation of their experiences, they may or not influence others' purchase behavior (Susskind, 2002). Customer satisfaction is considered a significant reason for positive word of mouth (De Matos and Rossi 2008; Swan and Oliver 1989; Zeithaml et al., 1996). Satisfied customers can create a positive impact if they recommend a particular service provider to their friends, families, and colleagues (Reichheld, 2003). The importance of word of mouth brings attention to the intention to recommend a predictor of the service provider's performance (Keiningham et al., 2007; Morgan \& Rego, 2006; Reichheld, 2003). Munhurrun (2012) showed that customer satisfaction has a significant impact on customers' intention to recommend. Based on the above review of literature, the following hypothesis was derived:

H8: Customer satisfaction positively influences the intention to recommend.

H9: Customer Satisfaction mediates the influence of the five dimensions of service quality on the intention to recommend

\section{Customer satisfaction and intention to switch}

Switching intention is typically arise from dissatisfaction with the current provider's performance of products or services. Although the switching intention was derived from the behavioral intention (Keaveney, 1995), switching intention indicates unfavorable outcomes for the service provider (Bansal \& Taylor, 1999; Han et al., 2009). According to Oliver (1980), customer satisfaction exists when customers experience a service and compare it with their expectations. If the performance meets or exceeds expectations, customers are generally satisfied. However, if the performance does not meet expectations, customers are typically displeased with that service, and then they switch to another service provider. Previous studies identified a relationship between customer satisfaction and switching intentions (Bansal and Taylor,1999; Cronin et al., 2000; Kotler et al., 2002; Jang et al., 2013). Bansal and Taylor (1999) explained that customer dissatisfaction results in a greater likelihood of switching. Also, Cronin et al. (2000) empirically tested the significant association between customer satisfaction and their intention to switch. Zeelenberg \& Pieters (2004) showed that dissatisfied customers are more likely to switch than are satisfied customers. The correlation between customer satisfaction and their intentions provides the fundamental service concept to the service operations that should 
satisfy customers' needs and avoid switching (Kotler et al., 2002; Jang et al., 2013). Based on the above review of literature, the following hypothesis was derived:

H10: Customer satisfaction negatively influences the intention to switch.

H11: Customer Satisfaction mediates the influence of the five dimensions of service quality on the intention to switch.

\section{Methodology}

A self-administrated questionnaire was used to collect the primary data of this study. The questionnaire was developed by Akbaba (2006) and divided into three parts. The first part measured customer expectations and perceptions of services offered by hotels. This part also consists of 29 service quality attributes positioned in the questionnaire's center column. Customers were asked to rate their responses in relation to these attributes on a five-point Likert scale from 1 (very low) to 5 (very high), which were placed on the left and right sides of the center column, the left side assessing customer expectations and the right side measuring the perceptions. The reason for using this layout with a five-point Likert scale is to overcome confusion, length of the questionnaire; boredom stemmed from two administrations in SERVQUAL.

The second part of the survey measured the customer perceptions of overall service quality, expectations, satisfaction, and behavioral intentions. Overall service quality was assessed using the same five-point Likert scale. However, a five-point Likert scale was used to measure the overall customer expectations range from: $(1=$ much less than expected to $5=$ greatly exceeded expectations). A five-point Likert scale was used to measure overall customer satisfaction: $(1=$ completely dissatisfied to $5=$ completely satisfied). A five-point Likert scale was used to measure behavioral intentions: $(1=$ strongly disagree to $5=$ strongly agree). The third part of the questionnaire measured the customers' characteristics.

A responsiveness sampling was used to target all the business travelers who stayed in three business hotels in Greater Cairo in Egypt. During their check-out periods, customers were approached and asked by receptionists if they would like to participate in this study. A total of 300 customers have filled out the questionnaire form and put it back in the collection box close to the reception desk, however 260 out of the 300 questionnaires were valid.

The Statistical Package for the Social Sciences version 22.0 was used to analyze the data. A paired sample $t$-test was performed to examine the significant differences between two means of expectations and perceptions. Reliability analysis was carried out to ensure the internal consistency of the scale items. Construct validity was used through factor analysis to ensure all the indicators in the scale measure the same construct (Flynn et al., 1995). Factor analysis was performed to explore the small dimension of the 29-attribute scale. Multiple regression analysis was carried out to identify the relative importance of the service quality factors in predicting overall customer satisfaction. 


\section{Demographics}

\section{Results}

As noticed from Table 1, most customers (35.8\%) fell into the 35-44-year age group, followed by the $25-34$-year age group $(26.2 \%)$. The respondents' highest proportion was males, who accounted for $66.2 \%$ of the sample as opposed to females $(33.8 \%)$. In terms of employment status, $58.1 \%$ of customers were self-employed, followed by $32.7 \%$ of professional people; then, $5.4 \%$ were students, and 3.8\% of customers were in "other jobs," such as "business representative, government official and retires." Regarding education levels, the largest respondent segments had a bachelor's degree (64.2\%), whereas the smallest respondent segments had a college degree (12.7). Regarding the respondents' frequency of a stay at hotels, most customers stayed at hotels once a year $(80.4 \%)$.

Table 1: Demographic Characteristics $(n=260)$

\begin{tabular}{|l|l|c|c|}
\hline \multirow{4}{*}{ Chare } & Frequency & Percentage \\
\hline \multirow{5}{*}{ Gender } & $18-24$ & 12 & 4.6 \\
\cline { 2 - 4 } & $25-34$ & 68 & 26.2 \\
\cline { 2 - 4 } & $35-44$ & 93 & 35.8 \\
\cline { 2 - 4 } & $45-54$ & 60 & 23.1 \\
\cline { 2 - 4 } & $55-64$ & 24 & 9.2 \\
\cline { 2 - 4 } & 65 or above & 3 & 1.2 \\
\hline \multirow{4}{*}{ Marital Status } & Male & 172 & 66.2 \\
\cline { 2 - 4 } & Female & 88 & 33.8 \\
\hline \multirow{5}{*}{ Occupation } & Single & 68 & 26.2 \\
\cline { 2 - 4 } & Married & 128 & 49.2 \\
\cline { 2 - 4 } & Other & 64 & 24.6 \\
\hline \multirow{5}{*}{ Education } & Professional & 85 & 32.7 \\
\cline { 2 - 4 } & Student & 14 & 5.4 \\
\cline { 2 - 4 } & Self-employed & 151 & 58.1 \\
\cline { 2 - 4 } & Other & 10 & 3.8 \\
\cline { 2 - 4 } & High School & 13 & 5.0 \\
\cline { 2 - 4 } & College degree & 33 & 12.7 \\
\cline { 2 - 4 } & Bachelor's degree & 167 & 64.2 \\
\cline { 2 - 4 } & Other & 47 & 80.1 \\
\hline Frequency of stay at & Once a year & 209 & 17.3 \\
\cline { 2 - 4 } & Twice a year & 45 & 2.3 \\
\cline { 2 - 4 } & Five times or more & 6 & \\
\hline
\end{tabular}

\section{Factor analysis}

Factor analysis was performed to reduce the service quality attributes from 29 to 21 interpretable set of factors. The principal component analysis and Varimax rotation were used to identify the correlated dimensions' underlying structure that would be suitable for further examination (Hair et al., 2010). In this study, a variable with factor loading greater than 0.4 and had eigenvalue equal to or greater than one was selected for interpretation and considered significant (see Table 2). Five main dimensions of service quality were extracted and named as follows: "tangibles," "adequacy in service supply," "understanding and caring, "assurance," and "convenience." The reliability coefficient (Cronbach's alpha) was conducted to test the internal consistency of these five service quality (Tabachnick and Fidell, 2007). The total Cronbach's $\alpha$ score of these five dimensions was 0.941. The individual alpha coefficients ranged from 0.885 to 0.935 , which indicates a good internal consistency between the items within each factor and across all the factors. Hence, the selfadministrated questionnaire can be considered to be reliable for analysis (Pallant, 2007). Generally speaking, the correlation matrix's overall significance was 0.000 with Bartlett's test of sphericity value of 4595.7, which indicated that the data matrix had sufficient correlation to the factor analysis. 
Based on factor analysis, factor one (assurance) was the most crucial factor for customers. It had four significant factor loadings, which explained $40.82 \%$ of the data's total variance, with an eigenvalue of 12.62. However, convenience was the least essential factor from customers' viewpoints, which explained $4.69 \%$ of the total variance and had three significant factor loadings.

Table 2: Results of factor analysis $(\mathrm{n}=260)$

\begin{tabular}{|c|c|c|c|c|c|c|}
\hline & 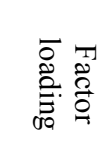 & F: & 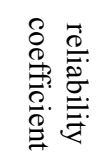 & 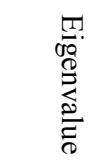 & 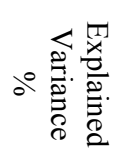 & $\begin{array}{l}T \\
\stackrel{T}{0} \\
\stackrel{0}{0}\end{array}$ \\
\hline The hotel keeps accurate guest records & 0.812 & 0.760 & 0.887 & \multirow[t]{4}{*}{12.62} & \multirow[t]{4}{*}{40.823} & \multirow{4}{*}{ 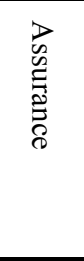 } \\
\hline $\begin{array}{l}\text { The hotel operating hours are } \\
\text { convenient for all their guests. }\end{array}$ & 0.690 & 0.507 & 0.892 & & & \\
\hline $\begin{array}{l}\text { The hotel provides its guests with a } \\
\text { safe place. }\end{array}$ & 0.601 & 0.519 & 0.890 & & & \\
\hline $\begin{array}{l}\text { Employees have in-depth occupational } \\
\text { knowledge. }\end{array}$ & 0.450 & 0.475 & 0.886 & & & \\
\hline $\begin{array}{l}\text { Employees are always willing to serve } \\
\text { customers }\end{array}$ & 0.892 & 0.757 & 0.895 & \multirow[t]{5}{*}{3.01} & \multirow[t]{5}{*}{14.952} & \multirow{5}{*}{ 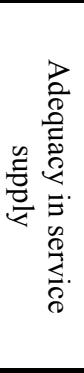 } \\
\hline $\begin{array}{l}\text { The hotel provides the services as they } \\
\text { were promised }\end{array}$ & 0.789 & 0.701 & 0.892 & & & \\
\hline $\begin{array}{l}\text { Hotel performs services right the first } \\
\text { time }\end{array}$ & 0.721 & 0.592 & 0.887 & & & \\
\hline $\begin{array}{l}\text { Employees give guests individualized } \\
\text { attention that makes them feel special }\end{array}$ & 0.704 & 0.615 & 0.895 & & & \\
\hline $\begin{array}{l}\text { Employees are always available when } \\
\text { needed }\end{array}$ & 0.652 & 0.483 & 0.888 & & & \\
\hline The hotel provides consistent services. & 0.735 & 0.618 & 0.894 & \multirow[t]{4}{*}{1.697} & \multirow[t]{4}{*}{5.743} & \multirow{4}{*}{ 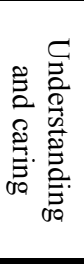 } \\
\hline $\begin{array}{l}\text { The hotel provides flexibility in } \\
\text { services according to guest demands }\end{array}$ & 0.598 & 0.455 & 0.896 & & & \\
\hline $\begin{array}{l}\text { Employees always treat guests in a } \\
\text { friendly manner }\end{array}$ & 0.530 & 0.490 & 0.890 & & & \\
\hline $\begin{array}{l}\text { Employees of the hotel understand the } \\
\text { specific needs of guests }\end{array}$ & 0.496 & 0.454 & 0.885 & & & \\
\hline $\begin{array}{l}\text { The service units of the hotel have } \\
\text { adequate capacity. }\end{array}$ & 0.809 & 0.453 & 0.891 & \multirow[t]{5}{*}{1.550} & \multirow[t]{5}{*}{5.276} & \multirow{5}{*}{ 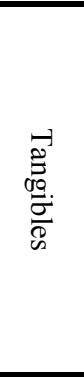 } \\
\hline $\begin{array}{l}\text { The atmosphere and equipment are } \\
\text { comfortable. }\end{array}$ & 0.718 & 0.596 & 0.885 & & & \\
\hline $\begin{array}{l}\text { The hotel has modern looking } \\
\text { equipment }\end{array}$ & 0.620 & 0.467 & 0.889 & & & \\
\hline $\begin{array}{l}\text { The equipment of the hotel works } \\
\text { properly }\end{array}$ & 0.562 & 0.453 & 0.886 & & & \\
\hline $\begin{array}{l}\text { Food and beverages served are } \\
\text { hygienic }\end{array}$ & 0.509 & 0.691 & 0.884 & & & \\
\hline It is easy to access to the hotel & 0.856 & 0.790 & 0.895 & \multirow[t]{3}{*}{1.814} & \multirow[t]{3}{*}{4.691} & \multirow{3}{*}{ 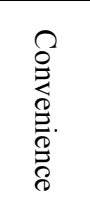 } \\
\hline $\begin{array}{l}\text { Getting information about the facilities } \\
\text { and services of the hotel is easy. }\end{array}$ & 0.771 & 0.781 & 0.897 & & & \\
\hline $\begin{array}{l}\text { The hotel resolves guest complaints } \\
\text { and compensates for the } \\
\text { inconvenience's guests go through }\end{array}$ & 0.463 & 0.523 & 0.856 & & & \\
\hline
\end{tabular}




\section{Paired-sample t-test}

A paired-sample t-test was used to compare the mean score of customer expectations with the mean score of customer perceptions. A paired sample $t$-test showed a significant difference of 20 out of 21 service quality attributes between expectation means and perceptions means $(\mathrm{t}<0.01)$. The most significant gaps between customer expectations and their perceptions were for three factors: 'it is easy to access to the hotel' $(-3.85)$; 'the hotel provides flexibility in services according to guest demands' (-2.31), and 'the hotel performs the services right at the first time' (-2.15). However, the smallest gaps were for: 'The equipment of the hotel works properly without causing breakdowns' (-0.70); 'Employees give guests individualized attention that makes them feel special' $(-0.55)$ and 'the hotel provides its guests a safe place' (-0.21).

Table 3: Results of paired-sample t-test

\begin{tabular}{|c|c|c|c|c|c|}
\hline Tangibles & $\begin{array}{l}\text { Expectations } \\
\text { Mean }\end{array}$ & $\begin{array}{l}\text { Perceptions } \\
\text { Mean }\end{array}$ & $\begin{array}{l}\text { Mean } \\
\text { Difference }\end{array}$ & t-value & $\begin{array}{l}\text { P- } \\
\text { value }\end{array}$ \\
\hline \multicolumn{6}{|l|}{ Tangibles } \\
\hline $\begin{array}{l}\text { The equipment of the hotel works properly } \\
\text { without causing breakdowns }\end{array}$ & 2.52 & 1.82 & -0.70 & 2.695 & .059 \\
\hline $\begin{array}{l}\text { The atmosphere and equipment are } \\
\text { comfortable. }\end{array}$ & 3.82 & 2.45 & -1.37 & 15.881 & .442 \\
\hline The hotel has modern looking equipment & 3.57 & 2.68 & -0.89 & -11.563 & .008 \\
\hline Food and beverages served are hygienic & 4.34 & 2.51 & -1.83 & -14.421 & .000 \\
\hline $\begin{array}{l}\text { The service units of the hotel have adequate } \\
\text { capacity. }\end{array}$ & 4.26 & 3.03 & -1.23 & -13.059 & .000 \\
\hline \multicolumn{6}{|l|}{ Adequacy in service supply } \\
\hline $\begin{array}{l}\text { The hotel provides the services as they were } \\
\text { promised }\end{array}$ & 4.06 & 2.37 & -1.69 & 1.895 & .000 \\
\hline $\begin{array}{l}\text { Employees are always willing to serve } \\
\text { customers }\end{array}$ & 2.65 & 2.09 & -0.56 & -10.445 & .000 \\
\hline Employees are always available when needed & 4.43 & 3.35 & -1.08 & -11.22 & .000 \\
\hline $\begin{array}{l}\text { The hotel performs the services right at the } \\
\text { first time }\end{array}$ & 4.57 & 2.42 & -2.15 & -5.694 & .000 \\
\hline The hotel provides consistent services. & 4.23 & 3.20 & -1.03 & -18.162 & .000 \\
\hline \multicolumn{6}{|l|}{ Understanding and caring } \\
\hline $\begin{array}{l}\text { Employees give guests individualized } \\
\text { attention that makes them feel special }\end{array}$ & 3.42 & 2.87 & -0.55 & -13.930 & .000 \\
\hline $\begin{array}{l}\text { The hotel provides flexibility in services } \\
\text { according to guest demands }\end{array}$ & 4.74 & 2.34 & -2.31 & -15.316 & .000 \\
\hline $\begin{array}{l}\text { Employees always treat guests in a friendly } \\
\text { manner }\end{array}$ & 4.37 & 3.06 & -1.31 & -3.804 & .017 \\
\hline $\begin{array}{l}\text { Employees of the hotel understand the } \\
\text { specific needs of guests }\end{array}$ & 3.75 & 2.26 & -1.49 & -18.673 & .000 \\
\hline \multicolumn{6}{|l|}{ Assurance } \\
\hline The hotel keeps accurate records & 4.63 & 3.34 & -1.29 & -11.392 & .000 \\
\hline $\begin{array}{l}\text { The hotel and its facilities have operating } \\
\text { hours convenient to all their guests. }\end{array}$ & 3.42 & 1.70 & -1.63 & -13.752 & .000 \\
\hline $\begin{array}{l}\text { The hotel provides its guests with a safe } \\
\text { place. }\end{array}$ & 2.22 & 2.01 & -0.21 & -13.116 & .000 \\
\hline $\begin{array}{l}\text { Employees have in-depth occupational } \\
\text { knowledge. }\end{array}$ & 4.63 & 3.52 & -1.11 & -7.723 & .000 \\
\hline \multicolumn{6}{|l|}{ Convenience } \\
\hline It is easy to access to the hotel & 4.28 & 0.43 & -3.85 & -2.422 & .000 \\
\hline $\begin{array}{l}\text { Getting information about the facilities and } \\
\text { services of the hotel is easy. }\end{array}$ & 4.08 & 2.28 & -1.26 & -7.1770 & .000 \\
\hline $\begin{array}{l}\text { The hotel resolves guest complaints and } \\
\text { compensates for the inconveniences guests go } \\
\text { through }\end{array}$ & 3.08 & 1.95 & -1.13 & -13.080 & .000 \\
\hline
\end{tabular}




\section{Multiple regression analysis}

The multiple regression analysis was performed to test the relationship between service quality factors (independent variables) and behavioral intentions (dependent variables). The results of multiple regression analysis indicated that the coefficient of determination $\left(R^{2}\right)$ is 0.56 , estimated that $52 \%$ of overall customer satisfaction variation is explained by the service quality factors (see Table 4 ). Also, the $F$ ratio, which measures whether the regression model's findings could have occurred by chance. The $F$ ratio has a value of 34.298 , which is significant at 0.000 , showing that the equation's findings would hardly occur by chance, and the regression model was meaningfully explaining the data. Multiple regression analysis was used to test the hypothesis of the current study.

Table 4 shows a statistically significant relationship between three dependent variables and customer satisfaction $(\mathrm{P}=0.000)$. Specifically, the perception of adequacy in service supply was the strongest predictor of customer satisfaction $(\beta=.40 ; \mathrm{t}=5.91)$, compared to the perception of understanding and caring $(\beta=.21 ; \mathrm{t}=3.49)$. This finding indicates that customers' perceptions of assurance will lead to their satisfaction. How employees understand customers' needs and deal with them will slightly impact customer satisfaction in business hotels. However, customer perceptions of tangibles $(\beta=.15 ; \mathrm{t}=2.85)$ and convenience $(\beta=.12 ; \mathrm{t}=1.76)$ were not significant factors predicting customer satisfaction. Based on these findings, $\mathrm{H} 1, \mathrm{H} 2$, and $\mathrm{H} 3$ were accepted, whereas $\mathrm{H} 4$ and $\mathrm{H} 5$ were rejected.

Table 4: The relationship between service quality dimensions and customer satisfaction

\begin{tabular}{|c|c|c|c|}
\hline \multirow{3}{*}{$\begin{array}{l}\text { Variables } \\
\text { Independents } \\
\end{array}$} & \multirow{2}{*}{\multicolumn{2}{|c|}{$\begin{array}{c}\text { Dependent } \\
\text { Customer Satisfaction }\end{array}$}} & \multirow[t]{3}{*}{ P-value } \\
\hline & & & \\
\hline & $\beta$ & $\mathbf{t}$ & \\
\hline Assurance & .33 & 4.33 & $.000^{*}$ \\
\hline Adequacy in service supply & .40 & 5.91 & $.005^{*}$ \\
\hline Understanding and caring & .21 & 3.49 & $.001 *$ \\
\hline Tangibles & .15 & 2.85 & $.080 *$ \\
\hline Convenience & .12 & 1.76 & $.120 *$ \\
\hline F Change & \multicolumn{2}{|c|}{38.19} & \\
\hline $\mathrm{R}^{2}$ & \multicolumn{2}{|c|}{0.56} & \\
\hline P value & \multicolumn{2}{|c|}{.000} & \\
\hline
\end{tabular}

As shown in Table 5, customer satisfaction is significantly predicting the three dependent variables of this study. Customer satisfaction had the most substantial influence on intention to recommend $(\beta=.83 ; \mathrm{t}=19.05)$, while it had the weakest influence on intention to switch $(\beta=.32 ; \mathrm{t}=7.15)$. The findings also showed a statically significant relationship between independent variables and customer satisfaction as a mediator was created $\left(\mathrm{R}^{2}=.56, \mathrm{P}=0.000\right)$. A significant relationship was also built between independent and dependent variables - intention to return $\left(\mathrm{R}^{2}=.36, \mathrm{P}=0.050\right)$, intention to recommend $\left(\mathrm{R}^{2}=.39, \mathrm{P}=0.000\right)$, and intention to switch $\left(\mathrm{R}^{2}=.22, \mathrm{P}=0.000\right)$.

Table 5: The relationship between customer satisfaction and behavioral intentions

\begin{tabular}{|l|c|c|c|c|c|c|}
\hline \multirow{2}{*}{ Variables } & \multicolumn{9}{|c|}{ Dependents } \\
\cline { 2 - 7 } & \multicolumn{2}{|c|}{ Intention to return } & \multicolumn{2}{c|}{$\begin{array}{l}\text { Intention to } \\
\text { recommend }\end{array}$} & \multicolumn{2}{c|}{ Intention to switch } \\
\hline \multicolumn{1}{|c|}{ Independent } & $\boldsymbol{\beta}$ & $\mathbf{t}$ & $\boldsymbol{\beta}$ & $\mathbf{t}$ & $\boldsymbol{\beta}$ & $\mathbf{t}$ \\
\hline Customer Satisfaction & .51 & $15.13^{*}$ & .83 & $19.05^{*}$ & .32 & $7.15^{*}$ \\
\hline $\mathrm{P}$ value & \multicolumn{2}{|c|}{.000} & \multicolumn{2}{c|}{.040} & \multicolumn{2}{c|}{.000} \\
\hline $\mathrm{R}^{2}$ & \multicolumn{2}{|c|}{.42} & \multicolumn{2}{c|}{480.5} & \multicolumn{2}{c}{.25} \\
\hline F Ratio & \multicolumn{2}{|c|}{256.9} & \multicolumn{3}{c}{66.2} \\
\hline
\end{tabular}

Note: $* \mathrm{p}<0.05$ 
Customer satisfaction (the mediating variable) was added into the three relationship models between independent and dependent variables to complete the third condition of Baron and Kenny (1986). A significant relationship will disappear if customer satisfaction fully mediates between independent variables and each dependent variable. In contrast, when the significance is reduced, customer satisfaction will partially mediate the relationship mentioned above (see Table 6).

Regarding each independent variable's significance, Table 6 indicates adequacy in service supply and caring are the only two dimensions of service quality that remained significant in predicting all dependent variables. It is also noticed that these dimensions' $\beta$ and $t$ values were decreased compared to those values in Table 5. This finding indicates customer satisfaction partially mediated the relationship between these two dimensions and intention to return, intention to recommend, and intention to switch. Moreover, the relationship between caring and the three dependent variables become significant after including customer satisfaction in the regression model. In contrast, a decrease in $\beta$ and $t$ values showed that customer satisfaction partially mediated these relationships. Furthermore, the findings indicated that assurance did not predict intention to recommend before and after adding the customer satisfaction in the model as there is no significant relationship.

Table 6: Customer satisfaction mediates dependent and independent variables.

\begin{tabular}{|c|c|c|c|c|c|c|c|c|}
\hline \multirow{3}{*}{$\begin{array}{l}\text { Variables } \\
\text { Independents }\end{array}$} & \multirow{2}{*}{\multicolumn{2}{|c|}{$\begin{array}{c}\text { Mediating } \\
\text { Customer } \\
\text { Satisfaction }\end{array}$}} & \multicolumn{6}{|c|}{ Dependents } \\
\hline & & & \multicolumn{2}{|c|}{$\begin{array}{c}\text { Intention to } \\
\text { return }\end{array}$} & \multicolumn{2}{|c|}{$\begin{array}{l}\text { Intention to } \\
\text { recommend }\end{array}$} & \multicolumn{2}{|c|}{$\begin{array}{c}\text { Intention to } \\
\text { switch }\end{array}$} \\
\hline & $\beta$ & $\mathbf{t}$ & $\beta$ & $t$ & $\beta$ & $\mathbf{t}$ & $\beta$ & $\mathbf{t}$ \\
\hline Assurance & .40 & $5.91 *$ & .28 & 3.84 & .29 & $3.27 *$ & .24 & $3.75 *$ \\
\hline $\begin{array}{l}\text { Adequacy in service } \\
\text { supply }\end{array}$ & .38 & $4.33^{*}$ & .32 & $5.20^{*}$ & .33 & $4.05 *$ & .41 & $6.39 *$ \\
\hline $\begin{array}{l}\text { Understanding and } \\
\text { caring }\end{array}$ & .23 & 3.49 & .24 & $3.37 *$ & .20 & 2.84 & .10 & 1.85 \\
\hline Tangibles & .17 & 2.85 & .12 & $2.58^{*}$ & .25 & 3.22 & .16 & $2.36^{*}$ \\
\hline Convenience & .12 & 1.76 & -.15 & -2.13 & .09 & $1.90 *$ & .21 & 3.78 \\
\hline $\mathrm{P}$ value & \multicolumn{2}{|c|}{.000} & \multicolumn{2}{|c|}{.050} & \multicolumn{2}{|c|}{.000} & \multicolumn{2}{|c|}{.000} \\
\hline $\mathrm{R}^{2}$ & \multicolumn{2}{|c|}{0.56} & \multicolumn{2}{|c|}{.36} & \multicolumn{2}{|c|}{.39} & \multicolumn{2}{|c|}{.22} \\
\hline F ratio & \multicolumn{2}{|c|}{38.19} & \multicolumn{2}{|c|}{20.64} & \multicolumn{2}{|c|}{31.55} & \multicolumn{2}{|c|}{14.71} \\
\hline
\end{tabular}

Note: $* \mathrm{p}<0.05$

The results also showed tangibles predicts only intention to return after adding customer satisfaction in the model, whereas $\beta$ and $t$ values decreased, which showed that customer satisfaction partially mediated these relationships. However, Table 7 shows that the tangibles dimension without customer satisfaction in the model significantly predicted intention to recommend and intention to switch, indicating that customer satisfaction fully mediated these relationships. Also, convenience predicts customers' intention to recommend before and after involving customer satisfaction in the model. However, the relationships between convenience, intention to return, and the intention to recommend have remained insignificant. This result means the convenience dimension with or without customer satisfaction did not predict the intention to return and switching intention. 
Table 7: The effect of customer satisfaction as a mediator

\begin{tabular}{|c|c|c|c|c|c|c|}
\hline \multirow{4}{*}{$\begin{array}{l}\text { Variables } \\
\text { Independents }\end{array}$} & \multicolumn{6}{|c|}{ Dependents } \\
\hline & \multirow{2}{*}{\multicolumn{2}{|c|}{$\begin{array}{c}\text { Model 1 } \\
\begin{array}{c}\text { Intention to } \\
\text { return }\end{array}\end{array}$}} & \multirow{2}{*}{\multicolumn{2}{|c|}{\begin{tabular}{|l} 
Model 2 \\
Intention to \\
recommend
\end{tabular}}} & \multirow{2}{*}{\multicolumn{2}{|c|}{$\begin{array}{c}\text { Model 3 } \\
\text { Intention to switch }\end{array}$}} \\
\hline & & & & & & \\
\hline & $\beta$ & $\mathbf{t}$ & $\beta$ & $\mathbf{t}$ & $\beta$ & $t$ \\
\hline Assurance & .13 & $1.71^{*}$ & .25 & 2.59 & .15 & $2.17 *$ \\
\hline Adequacy in service supply & .16 & $3.08^{*}$ & .31 & $3.97 *$ & .23 & $3.62 *$ \\
\hline Caring & .09 & $1.69 *$ & .05 & $.63^{*}$ & .02 & .77 \\
\hline Tangibles & .17 & $2.34 *$ & .21 & 2.58 & .10 & 1.45 \\
\hline Convenience & -.20 & -1.10 & .06 & $1.09^{*}$ & .14 & 2.11 \\
\hline Customer Satisfaction & .38 & $6.21 *$ & .54 & $7.81^{*}$ & .20 & $4.88^{*}$ \\
\hline $\mathrm{P}$ value & \multicolumn{2}{|c|}{.000} & \multicolumn{2}{|c|}{.000} & \multicolumn{2}{|c|}{.000} \\
\hline $\mathrm{R}^{2}$ & \multicolumn{2}{|c|}{0.44} & \multicolumn{2}{|c|}{.51} & \multicolumn{2}{|c|}{.25} \\
\hline F Ratio & \multicolumn{2}{|c|}{24.39} & \multicolumn{2}{|c|}{37.61} & \multicolumn{2}{|c|}{14.72} \\
\hline
\end{tabular}

Note: $* \mathrm{p}<0.05$

These findings draw the three sub-models of service quality dimensions, customer satisfaction, and behavioral intentions (see Figure 2). The findings indicated that after customer satisfaction had been included in the model, the $\mathrm{R}^{2}$ value was enhanced for the three models: intention to return, recommend, and switch. $\mathrm{R}^{2}$ value for model 1 increased from .36 to $.44, .39$ to .51 for model 2 and .22 to .25 for model 3 (see Table 7). The findings also showed that when customer satisfaction as a meditating variable was involved in models, the independent variables explained more variances in the dependent variables. Accordingly, $\mathrm{H} 9, \mathrm{H} 10$, and $\mathrm{H} 11$ are accepted.

Figure 2: Sub-models of service quality dimensions, customer satisfaction and behavioral intentions
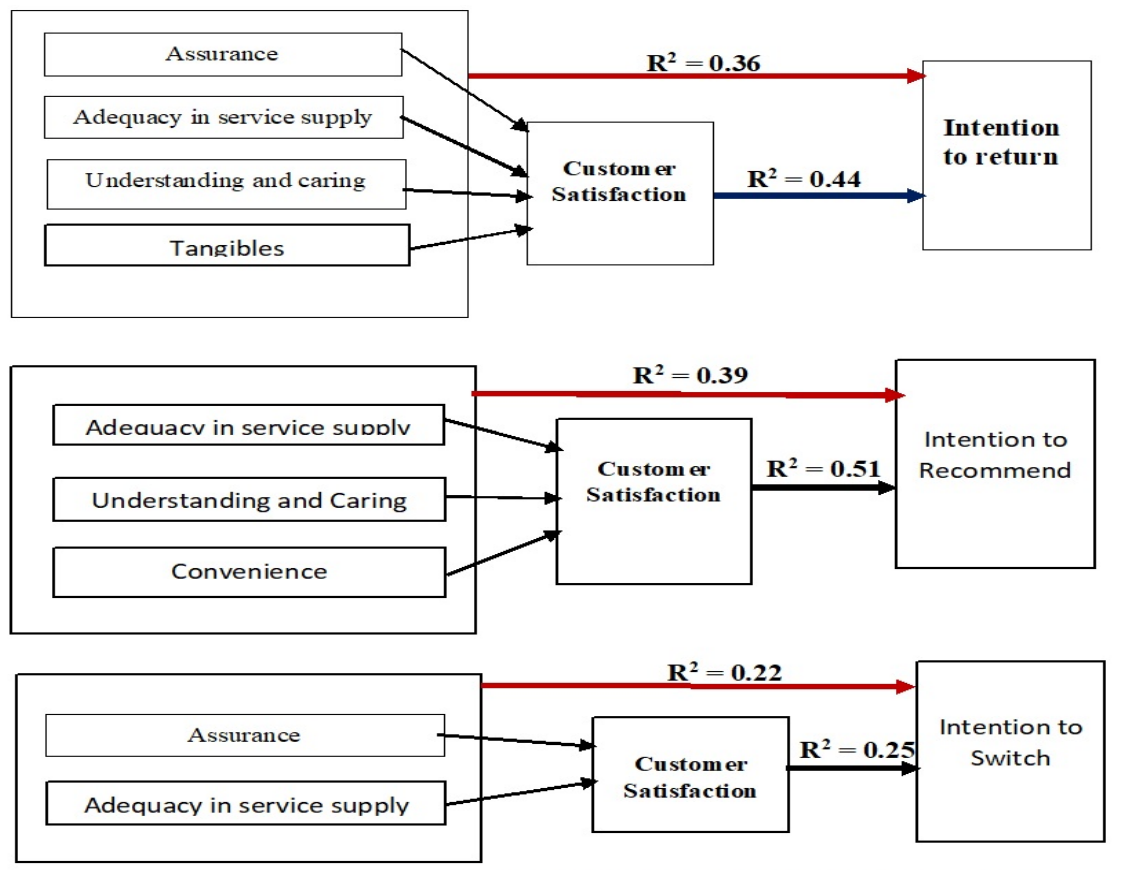

Notes: Direct path checks the relationship between independent and dependent variables; the Indirect path checks the relationship between independent and dependent variables through a mediator. 


\section{Discussion}

Service quality plays a critical role in the hotel industry's success, which cannot be denied. Identifying customers' specific expectations, the dimensions of the service quality, and their relative importance in achieving customer satisfaction for each specific segment of the hotel industry would undoubtedly help improve the service quality. The factor analysis findings suggested five main dimensions of service quality in business hotels: assurance, adequacy in service supply, understanding and caring, tangibles, and convenience.

This study used the five service quality dimensions of Akbaba (2006). The factor analysis findings showed that 21 factors were valid for further analysis compared to 23 factors in Akbaba's study. Eight factors were eliminated from the scale because they had a cross-loading and these factors are: 'materials associated with the services are adequate'; 'employees provide prompt service'; 'employees have the knowledge to provide information to guests in areas they would require'; 'the hotel provides the services at the time it promises to do so'; 'the hotel has visually appealing buildings and facilities'; 'employees of the hotel appear neat and tidy'; 'employees in still confidence in guests' and 'the hotel is also convenient for disabled guests.'

Meanwhile, the findings indicated that the business guests had the highest importance for the dimensions of assurance, adequacy in service supply, understanding and caring, tangibles, and donvenience. However, the findings of Akbaba's study (2006) found the business travellers had the highest expectations towards convenience, assurance, tangibles, adequacy in service supply, and understanding and caring. This finding may be because of the cultural difference between Turkey and Egypt, and the guests who visit Egypt may have different expectations than those who visit Turkey.

In the current study, the reliability score of service quality dimensions has also increased compared to Akbaba's (2006) study. In the present study, the total $\alpha$ value of the five major service quality dimensions is 0.941 , while the total $\alpha=0.931$ in Akbaba's study (2006). Moreover, the findings of the paired-sample t-test showed that customer perceptions of quality of service provided were lower than their expectations, indicating that the quality of service provided by business hotels did not meet customer expectations. The most significant gap between customer expectations and their perceptions was: 'it is easy to access the hotel' (-3.85). However, the smallest gap was: 'the hotel provides its guests a safe place' (-0.21). This finding may be because most business hotels in Cairo do not have facilities and services for disabled people. Also, for security reasons, some business hotels have more than one point of customer inspections to allow him/her to enter the hotel, especially if s/he arrives at the hotel in private transportation.

This study is the first attempt to use the model of customer satisfaction as a meditator between service quality dimensions and behavioral intentions. This study failed to prove that tangibles and convenience were antecedents of customer satisfaction. This finding may be because information technology has brought changes in the business environment, especially in creating value-added services that will increase customers' satisfaction (Zhu et al., 2002; Mariappan, 2006). Although Panda and Satyabrat (2014) found the physical environment significantly affected customer perceptions of service quality, they did not prove if the tangibles affect customer satisfaction or not. However, Ekinci et al. (2008) indicated that the physical environment was positively related to customer satisfaction.

This study's findings also showed that service supply adequacy, assurance, understanding, and caring were antecedents of customer satisfaction. Ekinci et al. (2008) found that customers used to evaluate service by using elements of staff behavior, and 
these elements have been recognized as a detriment to customer satisfaction. For example, Andaleeb and Conway (2006) pointed out that responsiveness influenced customer satisfaction. Lee et al. (2005)) found empathy influenced consumer satisfaction. In addition, the consequences of customer satisfaction in this study were intention to return, intention to recommend, and intention to switch. Past studies indicated that customer satisfaction positively influenced intention to return (Shanka and Taylor, 2003; O'Neill et al., 2006; Chen and Chen, 2010); intention to recommend (De Matos and Rossi 2008; Keiningham et al., 2007); intention to switch (Carter et al. 2014; Sahi et al., 2016).

The findings also indicated that customer satisfaction mediated the relationships between and service quality dimensions and behavioral intentions. As shown in Table 5, tangibles and convenience did not impact customer satisfaction. Hence, the outcomes of this study support 9 out of 11 hypotheses. Figure 1 suggests that the customer satisfaction route starts with achieving customers' assurance, perceptions towards adequacy in service supply, understanding and caring, and perceptions of tangibles, leading to positive customer behavioral intentions. In this study, it can also be noticed that adequacy in service supply is involved in the three models of customer satisfaction, showing the influential role of adequacy in service supply in predicting customer satisfaction, intention to return, intention to switch.

Based on the $\mathrm{R}^{2}$ value, Figure 1 also shows the model labeled (b), which is the bestfit model that explains customer satisfaction in the current study, followed by (a) and (c). The $\mathrm{R}^{2}$ values for these models improved after including customer satisfaction in the model of relationships between independent and dependent variables. For example, independent variables through customer satisfaction explained a total of $51 \%$ variance in customer intention to recommend. This finding means that the independent variables are better predicted than dependent variables through customer satisfaction. Moreover, figure 1 indicates that the weakest model was involved in the relationship between the independent variables and intention to switch. Perhaps other factors could mediate the relationship between independent variables, customer satisfaction, and intention to switch, such as switching costs (Bansal and Taylor, 1999). Thus, further research is needed to examine such relationships to see whether the customer satisfaction model will be improved with the intention to switch.

In this study, the findings are compared with other customer satisfaction studies and found that customer satisfaction models may result in customer intention to return, intention to recommend, and intention to switch. To the author's knowledge, this study, among other few studies to examine the relationship between each dimension of service quality and behavioral intentions in five-star hotels in Cairo in Egypt. This study's models merge all the variables used separately in previous studies of service quality, customer satisfaction, and behavioral intentions. This study concluded that when customers were satisfied with a hotel, they had a higher intention to recommend or revisit this hotel, and they were not likely to switch to other hotels.

\section{Conclusion}

The current study investigated customer satisfaction as a mediator between service quality dimensions and behavioral intentions in the Egyptian Hotel Industry. This study proved that assurance, adequacy in service supply, understanding, and caring were predictors for customer satisfaction. Customer satisfaction also had the most substantial influence on intention to return, intention to recommend, and prevent customers from switching from a hotel to another. These findings can encourage marketers to attempt to raise customer 
satisfaction with confidence in improving behavioral intentions. This study also provides hotel managers with insights into service quality dimensions that impact customer satisfaction and behavioral intentions.

Firstly, adequacy in service supply (reliability) is an important factor in influencing customers to return to a hotel or recommend it to a friend or relative and prevent them from switching. Secondly, this study's findings indicated that assurance was a critical factor for preventing customers' switching. Thus, hotel management should provide reliable service and accurate information in order to create a loyal customer base instead of spending a lot of money on advertising to attract new customers. Thirdly, understanding and caring contributed also to customer satisfaction and customers' intention to return and recommend. Therefore, hotel management should train the staff to give guests individualized attention that makes them feel special. The hotel managers should provide flexibility in services according to guest demands.

Fourthly, tangibles contribute directly to customers' intention to return. Thus, hotel managers should customize several aspects in hotels to full the desire of target markets for the physical environment. For instance, a hotel restaurant's color, design, music can be created to match customers' nationality, age, education level, and income. The above factors provide a good environment for the dining experience, which will result in building a strong relationship between customers and hotels. Finally, convenience contributes directly to customers' intention to recommend a hotel to a friend or relatives. Consequently, hotel managers should resolve guest complaints and compensate for the inconveniences guests go through. The hotel manager should also provide easy access to the hotel and provide a complete picture of its facilities and service to customers.

Although this study's findings indicated that quality performance (i.e., adequacy in service supply, assurance, understanding, and caring) in the sampled hotels was rationally good, lower ratings were identified for numerous factors. These factors involve but are not limited to: 'the hotel performs the services right at the first time'; 'the hotel provides flexibility in services according to guest demands' and 'it is easy to access to the hotel.' Thus, hotel managers should focus on the quality of staff behavior attributes because staff behavior had the most substantial influence on customer satisfaction. Based on the previous discussion, this study suggests the most critical dimensions of service quality in the hotels: 'assurance,' 'adequacy in service supply,' and 'understanding and caring.' These dimensions have different weights of importance about customer satisfaction and behavioral intentions.

\section{Limitations of this study and suggestions for further research}

This study examined customer satisfaction as a mediator between service quality dimensions and behavioral intentions in Greater Cairo in Egypt. Hence, to generalize this study's findings, another study should include several five-star hotels across Egypt. Since the Middle East countries have a similar culture, future research may apply this study's findings in one of those countries to see whether the findings will be the same or different. The current study focused on the service quality measures and switching intention roles of service performance. As an extension of this study, incorporating other crucial variables, such as switching barriers and service recovery activities into the proposed model, is recommended to better predict switching intention. 


\section{References}

Abu Alroub, A. S., Alsaleem, A.M., \& Daoud, A. A. (2012). Service quality and its impact on customer satisfaction tourist restaurants (A field study on the tourist restaurants / Amman), Interdisciplinary Journal of Contemporary Research in Business, 4(1), 364-379.

Akbaba, A. (2006). Measuring service quality in the hotel industry: A study in a business hotel in Turkey, International Journal of Hospitality Management, 25(2), 170-192.

Andaleeb, S.S., \& Conway, C. (2006). Customer satisfaction in the restaurant industry: An examination of the transaction-specific model. Journal of Services Marketing, 20(1), 3-11.

Angelova, B., \& Zeqiri, J. (2011). Measuring Customer Satisfaction with Service Quality Using American Customer Satisfaction Model (ACSI Model). International Journal of Academic Research in Business and Social Sciences, 1- 10.

Bansal, H. \& Taylor, S. (1999). The service provider switching model (SPSM): A consumer switching behavior model in the services industry. Journal of Service Research, 21, 200-218.

Bansal, H., \& Taylor, S. (1999). The service provider switching model (SPSM): a model of consumer switching behavior in the services industry. Journal of Service Research, 2(2), 200-218

Bigné, J., Sánchez, M., \& Sánchez, J. (2001). Tourism image, evaluation variables, and after purchase behavior: inter-relationship, Tourism Management, 22(6), 607-616.

Burnham, T., Frels, J., \& Mahajan, V. (2003). Consumer Switching Costs: A Typology, Antecedents, and Consequence. Journal of the Academy of Marketing Science, 31(2), 109-126.

Cai, L.A., Wu, B., \& Bai, B. (2003). Destination image and loyalty, Cognizant Communication Corporation, 7, 153-162.

Carter, M., Wright, R., Thatcher, J., \& Klein, R. (2014). Understanding online customers' ties to merchants: The moderating influence of trust on the relationship between switching costs and e-Loyalty, European Journal of Information Systems, 23(2), 185-204.

Chacko, H. E., Williams, K., \& Schaffer, J. (2012). A Conceptual Framework for Attracting Generation $\mathrm{Y}$ to the Hotel Industry Using a Seamless Hotel Organizational Structure. Journal of Human Resources in Hospitality \& Tourism, 11(2), 106-122

Chen, C., \& Chen, F. (2010). Experience quality, perceived value, satisfaction, and behavioral intentions for heritage tourists. Tourism Management, 31, 29-35.

Chen, C., \& Tsai, D. (2007). How destination image and evaluative factors affect behavioral intentions? Tourism Management, 28, 1115-1122.

Chen, J., \& Gursoy, D. (2001). An investigation of tourists' destination loyalty and preferences, International Journal of Contemporary Hospitality Management, 13, $79-86$.

Chi, C. \& Qu, H. (2008). Examining the structural relationship of destination image, tourist satisfaction, and destination loyalty: an integrated approach. Tourism Management, 29(4), 624-636.

Creswell, J., \& Clark, V. (2011). Designing and conducting mixed methods research. $2^{\text {nd }}$ edition. USA: SAGE Publications Inc. 
Cronin, J., Brady, M., \& Hult, G. (2000). Assessing the effects of equality, value, and customer satisfaction on consumer behavioral intentions in service environments. Journal of Retailing, 76(2), 193-218.

Cronin, J.J., Brady, M.K. \& Hult, G.T.M. (2000). Assessing the effects of quality, value, and customer satisfaction on consumer behavioral intentions in service environments. Journal of Retailing, 76(2), 193-218.

Curry, A. (1999). Innovation in public service management. Managing Service Quality, 9(3), 180-190.

Davies, M. (2007). Doing a successful research project: Using qualitative or quantitative methods. New York: Palgrave Macmillan.

De Matos, C., \& Rossi, C. (2008). Word-of-mouth communications in marketing: a metaanalytic review of the antecedents and moderators, Journal of the Academy of Marketing Science, 36(4), 578-596.

Ebrahimpour, A., \& Haghkhah, A. (2010). The role of service quality in the development of the tourism industry. SSRN Electronic Journal. DOI: 10.2139/ssrn.1668453

Egyptian Hotel Association (2012). The Egyptian Hotel Guide. Thirty Second Edition.

Ekinci, Y., Dawes, P.L., \& Massey, G.R. (2008). An extended model of the antecedents and consequences of consumer satisfaction for hospitality services. European Journal of Marketing, 42(1/2), 35-68.

El Saghier, N. (2015). Managing Service Quality: Dimensions of service quality: a study in Egypt. International Journal of African and Asian Studies, 9, 56-64.

Flynn, B., Schroeder, R., \& Sakakibara, S. (1995). The impact of quality management practices on performance and competitive advantage. Decision Sciences, 26(5), 659-691.

Fornell, C. (1992). A national customer satisfaction barometer: The Swedish experience. Journal of Marketing, 56(1), 6-21.

Frei, F. X., Kalakota, R., Leone, A. J., \& Marx, L. M. (1999). Process Variation as a Determinant of Bank Performance: Evidence from the Retail Banking Study. Management of Science, 45(9), 1210-1220.

Gagnon, G. \& Roh, Y. (2008). The impact of customization and reliability on customer satisfaction in the U.S. lodging industry, Journal of quality assurance in hospitality and tourism, 8(3), 60-78.

Hair, J., Black, W., Babin, B., \& Anderson, R. (2010), Multivariate Data Analysis: A Global Perspective, NJ: Pearson Education.

Han, H., \& Ryu, K. (2009). The roles of the physical environment, price perception, and customer satisfaction in determining customer loyalty in the restaurant industry. Journal of Hospitality Tourism, 33(4), 487-510.

Han, H., Back, K., \& Barrett, B. (2009). Influencing factors on restaurant customers' revisit intention: the roles of emotions and switching barriers. International Journal of Hospitality Management, 28, 563-572.

Harr, K. K. (2008). Service dimensions of service quality impacting customer satisfaction of fine dining restaurants in Singapore", UNLV Master's thesis. Retrieved from: http://digitalscholarship.unlv.edu/thesesdissertations/686.

Homburg, C., \& Giering, A. (2001). Personal characteristics as moderators of the relationships between customer satisfaction and loyalty. An empirical analysis, Psychology, and Marketing, 18, 43-63.

Hossain, M. (2019). Impact of Perceived Service Quality dimensions on Customer Satisfaction in Hospitality Industry. Global Review of Research in Tourism, 
Hospitality and Leisure Management (GRRTHLM) An Online International (Double-Blind) Refereed Research Journal, 5(1), 683-699

Iberahim, H., Mohd Taufik, N., Mohd Adzmir, A., \& Saharuddin, H. (2016). Customer Satisfaction on Reliability and Responsiveness of Self Service Technology for Retail Banking Services, Fifth International Conference On Marketing and Retailing (5TH income), Procedia Economics and Finance 37( 2016 ) 13 - 20.

Keaveney, M. (1995). Customer switching behavior in service industries: an exploratory study. Journal of Marketing, 59, 71-82.

Keiningham, T., Cooil, B., Aksoy, L. \& Weiner, J. (2007). The value of different customer satisfaction and loyalty metrics in predicting customer retention, recommendation, and share-of-wallet, Managing Service Quality, 17(4), 361-384.

Kotler, P., Armstrong, G., \& Cunningham, P. (2002). Principles of Marketing. PrenticeHall, Englewood Cliffs, NJ.

Lee, D. Y., Kang, C., Lee, J., \& Park, S. (2005). Characteristics of exemplary altruists, Journal of Humanistic Psychology, 45(2), 146-155.

Luk, S., \& Layton, R. (2002). Perception gaps in customer expectations: Managers versus service providers and customers, The Service Industries Journal, 22(2), 109-128.

Mariappan, V. (2006). Changing the way of banking in India. Journal of Economics and Behavioural Studies, 26(2), 26-34.

Morgan, N. \& Rego, L. (2006). The value of different customer satisfaction and loyalty metrics in predicting business performance. Marketing Sci., 25(5),426-439.

Munhurrun, P. (2012) Perceived service quality in restaurant services: Evidence from Mauritius. International Journal of Management and Marketing Research, 5(3), pp.1-14.

Niininen O., Szivas, E., and Riley, M. (2004). Destination loyalty and repeat behavior: An application of optimum stimulation measurement. International Journal of Tourism Research, 6, 439-447.

Oliver, R. (1980). A cognitive model of the antecedents and consequences of satisfaction decisions. Journal of Marketing Research, 17, 460-469.

Omar, H., Bin Saadan, K., \& Bin Seman, K. (2015). Determining the influence of the reliability of service quality on customer satisfaction: the case of Libyan Ecommerce customers, International Journal of Learning and Development, 5(1), 86-89.

O'Neill, J. W., Mattila, A., \& Xiao, Q. (2006). Hotel guest satisfaction and brand performance: The effect of Franchising Strategy. Journal of Quality Assurance in Hospitality and Tourism, 7(3), 25-39.

Oppermann, M. (2000). Tourism destination loyalty. Journal of Travel Research, 39, 7884.

Pallant, J. (2007). SPSS: A Step by Step Guide to Data Analysis Using SPSS for Windows (Version 15), Crows Nest, NSW: Allen and Unwin.

Panda, T., \& Das, S. (2014). The role of tangibility in service quality and its impact on external customer satisfaction: a comparative study of hospital and hospitality sectors, IUP Journal of Marketing Management, 13(4), 53-69.

Parasuraman, A., Zeithaml, V. A., and Berry, L. L. (1985). A conceptual model of service quality and its implications for future research. Journal of Marketing, 49(4), 41-50.

Parasuraman, A., Zeithaml, V., \& Berry, L. (1998). SERVQUAL: A multiple-item scale for measuring consumer perceptions of service quality. Journal of Retailing, 64(1), $12-40$. 
Petrick, J. (2004). Are loyal visitors desired visitors? Tourism Management, 25(4), 463470.

Pike, S. (2002). Destination image analysis - A review of 142 papers from 1973-2000. Tourism Management, 23(5), 541-549.

Pizam, A., Shapoval, V., \& Ellis, T. (2016). Customer satisfaction and its measurement in hospitality enterprises: a revisit and update. International Journal of Contemporary Hospitality Management, 28(1), 2-35.

Radojevic, Stanisic, \& Stanic. (2015). Ensuring positive feedback: Factors that influence customer satisfaction in the contemporary hospitality industry. Tourism Management, 51, 13-21.

Reichheld, F. (2003). The one number you need to grow, Harvard Business Review. 81(12), 46-54.

Ryu, K., \& Jang, S. (2008). DINESCAPE: A scale for customers' perception of dining environment. Journal of Food Service Business Research, 11(1), 2-22.

Sahi, G. K., Sambyal, R., \& Sekhon, H. S. (2016). Analyzing customers' switching intentions in the Telecom sector, Journal of Global Marketing 29(3), 156-169.

Said, A., Shuib, A., Ayob, N., \& Yaakub, F. (2013). An Evaluation Of Service Quality From Visitors' Perspectives: The Case Of Niah National Park In Sarawak. International Journal of Business and Society, 14(1), 61-78.

Salazar, A., Costa, J., \& Rita, P. (2010). A service quality evaluation scale for the hospitality sector. Worldwide Hospitality and Tourism Themes, 2(4), 383-397.

Saleh, F., \& Ryan, C. (1992). Analyzing service quality in the hospitality industry using the SERVQUAL model, Services Industries Journal, 11(3), 324-343.

Santos, J.( 2002), From intangibility to tangibility on service quality perceptions: a comparative study between consumers and service providers in four service industries. Managing Service Quality, 12(5), 292-230.

Shanka, T., \& Taylor, R. (2003). An investigation into the perceived importance of service and facility attributes of hotel satisfaction. Journal of Quality Assurance in Hospitality and Tourism, 3/4(4), 119 - 134.

Shi, W., Chen, J., \& Ma, J. (2011). A study of customer loyalty based on switching cost and brand attachment. The Journal of China Universities of Posts and Telecommunications, 18(1), 136-141.

Susskind, A. (2002). I told you so: restaurant customers' word-of-mouth communication patterns. Cornell Hotel and Restaurant Administration Quarterly, 43(2), 75-85.

Swan, J. E. \& Oliver, R. (1989), Postpurchase Communications by Consumers, Journal of Retailing, 65 (4), 516-533.

Tabachnick, B. \& Fidell, L. (2007). Using multivariate statistics, Boston: Allyn and Bacon.

Ting, S. (2014). The relationship between customers' switching cost and repurchase intention: The moderating role of satisfaction, Journal of Service Science and Management, 7, 313-322.

Um, S., Chon, K., \& Ro, Y. (2006). "Antecedents of revisit intention," Annals of Tourism Research, 33(4), 1141-1158.

Weiss, R. (2003). The relationship between restaurant attributes satisfaction and return intent in U.S. theme restaurants. Unpublished master's thesis, University of Nevada, Las Vegas, United States. 
Weiss, R., \& Feinstein, A. H., Dalbor, M. (2004). Customer satisfaction of theme restaurant attributes and their influence on return intent, Journal of foodservice business research, 7(1), 23-41.

Zeelenberg, M., Beattie, J., van der Pligt, J., \& de Vries, N. K., 1996. Consequences of regret aversion: Effects of expected feedback on risky decision making. Organizational Behavior and Human Decision Processes, 65(2): 148158.

Zeithaml, V. A., Bitner, M.J., \& Gremler, D.D. (2012). Services marketing: integrating customer focus across the firm, U.K.: McGraw-Hill Education.

Zeithaml, V.A., Berry, L. L., \& Parasuraman, A. (1996). The Behavioral Consequences of Service Quality, Journal of Marketing, 60(2), 31-46.

Zeithaml, V.A., Parasuraman, A., \& Berry, L.L. (1990), Delivering quality service: balancing customer perceptions and expectations, New York: The Free Press.

Zhu, F. X., Wymer, W., \& Chen, I. (2002). IT-based services and service quality in consumer banking, International Journal of Service Industry Management, 13(1), 69-90. 